\title{
Criminology and the Anthropocene
}

\section{Clifford Shearing}

\author{
University of Cape Town \\ Griffith University \\ University of Montreal \\ Australian National University
}

Final draft of paper subsequently published as:

Shearing, C. (2015). Criminology and the Anthropocene. Criminology and Criminal Justice, 15(3), 255-269. 


\begin{abstract}
The paper explores how criminology is responding to, and might respond to, the challenges presented by changes in earth systems, and the reasons for them, that the term "Anthropocene" signals. It begins with a very brief review of these developments and the meaning of the term. It then examines the responses within criminology that have emerged under the sign "green criminology". Thereafter it explores how criminology might respond to the challenges of the Anthropocene by using a "security governance" lens.
\end{abstract}

\title{
Keywords
}

criminology, environmental security, anthropocen 


\section{Criminology and the Anthropocene}

\section{Clifford Shearing ${ }^{1}$}

A critique is not a matter of saying that things are not right as they are. It is a matter of pointing out on what kinds of assumptions, what kinds of familiar, unchallenged, unconsidered modes of thought the practices that we accept rest (Foucault, 1988: 155 cited in Dalby, 2007).

All of this suggests quite clearly that we need to rethink our identities as agents of geological change, and in the process understand humanity's role in the larger order of things (Dalby, 2007: 112).

\section{Introduction $^{2}$}

I would like to begin with a memory, an emblematic event from my childhood that stimulated an embryonic personal recognition of the Anthropocene. An awareness that has become more and more consuming as I have reflected, with increasing concern, on the world my grandchildren will inherent.

Some sixty odd years ago my father and I were driving down the coast, south of the City of Durban where I grew up. As I recall, we were driving in a splendid navy blue Buick with a wide running board upon which I used to love to stand when I met my father at the gate of the drive that ran up alongside my parents' grocery shop - above which was our home - as he returned after being out somewhere.

The day of our drive was a lovely clear day. The bright green of sugarcane fields were interspersed with the darker greens of indigenous coastal forests. This created a

\footnotetext{
${ }^{1}$ I would like to thank my colleague Jan Froestad from Bergen University with whom I have been exploring responses to the Anthropocene. This paper expresses some of our shared thinking. I would also like to thank Francisca Zimmermann for her assistance in the preparation of this paper.

${ }^{2}$ This paper is based on an invited lecture that I intended to present at the Annual Meeting of the Journal of Criminology and Criminal Justice in Leeds in early October 2014. Unfortunately I was unable to attend this meeting due to a minor, but badly timed, health hiccup. As a result the planned event was cancelled at the last moment. This paper is based on the presentation I intended to give. While I have added references, the paper reflects the conversational style, the structure and the content of my intended presentation.
} 
beautiful patchwork of colour that I enjoy to this day.

As we approached the little seaside town of Umkomaas, at a point where the road was a few hundred meters above sea level, we had an uninterrupted view of a factory, of some sort, located at the edge of the Indian Ocean, into which the factory was spewing a dark brown muck. This had created a sizable brown stain that had spread out into the ocean. On seeing this I immediately panicked - this panic is still very real to me as I share this story.

I turned to my father, alarmed, and asked: "Dad, what are they doing to the sea?"

My father turned to me reassuringly and said, in a kind and gentle voice: "Clifford, don't worry. The sea is so big, and that factory is so small, that it can't hurt the sea."

My father's message was clear and simple. The earth is so big and we humans are, in comparison, so small that it doesn't matter how we engage with the earth, as we cannot affect it. The implication was that I could, and should, treat the earth - in Heidegger's (1977) phrase as a "standing reserve" - as an inexhaustible warehouse, a cup that always "runneth over" (Psalm 23:6). Within this framing, the natural world is conceived of as an Umwelt, something that exists "over there" that "surrounds us and sometimes intrudes on our plans, but always remains separate" from our "social-only" domain (Hamilton, 2013b:online, see also Hamilton, 2013a).

This understanding of humans, and their relationship with earth systems, is certainly not new (see, for example, Lynn White's (1967) discussion of the "historical roots of our ecological crisis") and many have argued that this is a "way of seeing", to use Dorothy Smith's (1987) phrase, that has fundamentally shaped human engagements with earth systems (see for example, Tallacchini, 1998; and more recently Natali, 2013). 


\section{The Anthropocene}

This little story leads me to my title and the term "Anthropocene".

The "Anthropocene" (Crutzen and Stoemer, 2000) ${ }^{3}$, as most readers will know, refers to a posited new geological era that has been shaped by the "cumulative impact of civilization" (Syvitski, 2012:14) on earth systems. One of the many features that distinguish the Anthropocene is that, in the words of the manager of climate monitoring at the Australian Bureau of Meteorology in January 2013, "Everything that takes place in the climate system now is taking place on a planet which is a degree hotter than it used to be" (Hamilton, 2013b:online).

The geological era that this new age is said have replaced is the Holocene, a period that began some 12,000 years ago following the last Ice Age. The Holocene was a period of "remarkable climatic stability and clemency that allowed civilization to flourish" (Hamilton, 2013b:online; see also Hamilton, 2013a). These benign climatic conditions have proved to be very consequential as they freed humans to "finally make their mark" (Syvitski, 2012:12) and shifted their geological status from bit players to "geological agents" (Chakrabarty, 2009). It is this shift in the status of humans as biophysical agents within earth systems, enabled by the Holocene, that has ushered in the "Age of Humans" (Hamilton, 2013b:online). As Syvitski (Syvitski, 2012:12) notes, while this shift occurred "stealthily at first" it soon evolved "at an astonishing pace" (see also Tudge, 1998). "Suddenly, in geological terms, there is a new dominant life form loose in the biosphere and it is changing numerous facets of life rapidly" (Dalby, 2013:30; see also Dalby, 2014). In short, albeit "unintentionally" (Chakrabarty, 2009) and "accidentally" (Halsey, 2013), the biophysical realm (Nature) has been transformed from God's realm into, in Garfinkelian terms (Garfinkel, 1967), a human “accomplishment”.

Today, humans can no longer be conceived of as social actors operating exclusively within a social sphere of human-to-human engagements. We must now be conceived of as integral to earth systems. We act today, to borrow a term from Latour (2005), as biophysical "actants" who have, through our actions, significantly reshaped the earth.

\footnotetext{
${ }^{3}$ The Anthropocene Working Group of the International Commission on Stratigraphy's Subcommision on Quarternary stratigraphy is currently considering accepting the term 'Anthropocene' as a formalized new geological epoch in the geological time scale (Corlett, 2015; Finney, 2014).
} 
As geological agents, humans are slowly reconceiving themselves as biophysical beings interacting other biophysical beings. This is a different "death of the social" from the one to which Rose (1996) drew our attention, but it is a "death of the social" nonetheless. Today we know, beyond a shadow of a doubt, that Durkheim's social world is most certainly not a sui generis reality that exists independently of the biophysical realities of earth systems.

As we humans have slowly but surely come to recognize this change in our status, we have begun to question foundational assumptions about ourselves as a "social-only domain", separate from "the natural world 'over-there' that surrounds us" (Hamilton, 2013b:online) as was formed during the Holocene. These assumptions have long been articulated by a series of influential thinkers, from Descartes through Kant to Durkheim. At the forefront of this questioning have been scholars like Latour who have argued that the separation of the social and natural worlds (that has been so central to modernity) constitutes a flawed illusion - in Latour's (1993) words - and title of his book - "we have never been modern".

Central to this emerging reframing have been commentaries on the separation of the natural and social sciences (see Braithwaite, 2000) and ideas about how to move beyond this. Crucial to this have been attempts to rethink the social sciences and the "pre-Anthropocene" (Hamilton, 2013b:online) foundational assumptions upon which they have been constructed (Palsson, 2013; see also Hackmann et al. 2014). Hamilton (Hamilton, 2013b:online) expresses this with a nice flourish when he writes: "After all, it was not just the landscape that [has been] scorched ... but modernity itself".

It is to this rethinking and its implications for criminology that I now turn.

\section{Whither Criminology?}

The realisation that we humans are powerful biophysical agents invites us, as criminologists, to ask what criminology might be, and should be, in the Anthropocene? As we seek to develop new criminological imaginations (White, 2003) we have no option but to start from where we are now and in doing so to "peer through the fog of modernism" (Hamilton 2013b:online). Or in more colloquial terms, we have no option but to pull ourselves up by our bootstraps. As we do this pulling we need, as Larner (2011: 320) has noted, to be wary of "totalizing and epochal thinking" and to seek instead "nuanced" and "heterogeneous" responses that recognize the complexity and uncertainties the Anthropocene references. Fortunately the necessity of drawing upon our existing bootstraps will encourage us to 
recognize continuities, as well as disruptions, as the Anthropocene era unfolds.

However, having said this, figuring out where we are now and how we might proceed is not as simple as it seems, as there is more than one criminology -- more than one pair of boots on whose bootstraps we can draw as we seek to reimagine ourselves.

In more formal language: we, as criminologists, are going to have to start, as March (1991) has argued, by "exploiting" what we have, before we will be in a position to innovate in ways that will carry us beyond our present.

Hegel's thoughts on this predicament are relevant.

Philosophy as the thought of the world, does not appear until reality has completed its formative process and made itself ready.

When philosophy paints its grey in grey, one form of life has become old then a configuration of life has grown old and by means of grey cannot be rejuvenated, but only known. The Owl of Minerva takes flight only when the shades of night are gathering (Hegel, 1896:xxx).

The challenge we face in asking the question, "What might criminology be in the Anthropocene?", is how to enable our criminological Owl of Minerva to spread its wings as dusk settles on our Durkheimian era. A difficult task indeed. As we engage in this task we might take comfort from the Canadian poet, Leonard Cohen (1992).

Ring the bells that still can ring

Forget your perfect offering

There is a crack, a crack in everything

That's how the light gets in.

As we reinvent criminology, in ways that will enable us to respond to the Anthropocene we might find it useful to follow Cohen's advice and look for cracks.

\section{Green Criminology}

In finding cracks I would like to turn first to what has already happened, and is happening, within criminology, as criminologists have begun to respond to the challenges of the Anthropocene by a small, but active, group of "green" criminologists. 
At the centre of this work has been an understanding of criminology as both a crime-ology and a harm-ology (Hillyard, 2004; Hillyard and Tombs, 2007). As a consequence, a central feature of this work has been a broadening of "crime" beyond its established domain of human-to-human harms to include human-to-thing and thing-to-human harms, such as pollution, harms to the natural habitats of other species, harms to other species, and so on (for some key contributions to green criminology, see Lynch, 1990; Lynch and Stretesky, 2003; Halsey and White, 1998; Halsey, 2004; White, 2003; White, 2009; Gibbs et al., 2010; Brisman and South, 2013; South and Brisman, 2013; White, 2014; White and South, 2013).

These sweeping generalizations undoubtedly caricature "green criminology" and in doing so glosses the many debates within it about how this criminology, which has roots that go back at least to the 1980s, should be conceived (see for example Halsey and White, 1998; Halsey, 2004). Notwithstanding these caveats, this flattened account does provide, I hope, a useful characterisation of much that has been happening under the sign of "green criminology" and its cousin "conservation criminology". Importantly, the application of "governing through crime" (Simon, 2007) to respond to the challenges of the Anthropocene (such as the loss of biodiversity, pollution, green-house gas emissions) has made, and is making, a significant contribution. As this has happened, green criminologists have been developing an impressive body of scholarly work.

However, as significant and important as these developments have been, they have for the most part, only explored one set of the available pathways within criminology - one set of boots and one set of bootstraps. There is at least one other pair of criminological boots that can be, and should be explored, as criminology confronts the challenges of the Anthropocene.

\section{Criminology as a security-ology}

Mariana Valverde recognized this alternative in her opening lines of her "Criminology and Criminal Justice Lecture” at the Annual Meeting of the Journal of Criminology and Criminal Justice at the University of Leeds, in 2013. In her remarks Mariana spoke of a

...redefinition of criminology as the study not of crime and crime-control but of security - that is, the study of the provision of security, the guaranteeing of security assemblages, and the ongoing governance of security (Valverde, 2013:1).

This emerging criminology, as a security-ology, and a risk-ology, has pursued four principal 
directions.

1. First, it has sought, like Hillyard (2004) and green criminologists, to broaden the set of harms that fall within criminology's gaze.

2. Second, as part of this broadening, it has sought to shift the focus of criminology beyond the state, to a wider set of "auspices" and "providers" (Bayley and Shearing, 2001) of "security governance" (Johnston and Shearing, 2003).

3. Third, it has sought to refocus criminological attention from past-focused governance processes to more forward-looking ones that seek to anticipate and pre-empt the realization of harms.

4. Finally, it has explored the normative implications of these developments.

This research and thinking - much of it inspired by Ulrich Beck (1992) and his conception of a "risk society" - has been led by criminological scholars, such as the late Richard Ericson, Mariana Valverde, Jonathan Simon, Pat O’Malley, Benoit Dupont, Lucia Zedner, Les Johnston, Jennifer Wood, and Kevin Haggerty, to name but a few. These scholars have developed a very rich literature on what might be termed, following Simon, the "governance of security through risk". This rich literature provides a useful set of resources that can be drawn upon as criminology re-thinks itself within the context of the Anthropocene.

It is these criminological bootstraps that I, together with a very small group of geographically and institutionally diverse colleagues, have begun to draw upon as we have sought to explore how these security governance ideas, developed within the umbrella of criminology, might be mobilized to consider what we have termed "environmental security". Our aim, in undertaking this work, has been to complement, and hopefully add value to, what has been, and is being, accomplished under the banner of "green criminology".

\section{A Terminological Note}

Before I turn to this work, let me pause for a moment so that I can provide a brief reflection on the terms "security" and "environmental security", as these terms already enjoy

\footnotetext{
${ }^{4}$ Although he does not use the term, Beck (1992) used the developments that the Anthropocene references to illustrate his argument about the shifts in the nature of risk, which characterize what he termed "risk society".
} 
considerable currency within other literatures - something that Lucia Zedner (2009) has masterfully explored in her wonderful book entitled Security.

In using the term "security", the group of colleagues with whom I have been working have drawn upon a well-established criminological concern with securing conditions that will promote interpersonal "peace", in the Hobbesian sense of peace, as the presence of credible assurances of safe spaces within which people can live, work and play (Shearing and Johnston, 2013:7). Within criminology, a tight coupling of the terms "security" and "safety" has referenced this historical lineage. For example, in the use of the term the "safety and security web" (Council for Canadian Academies, 2014).

In drawing on this tradition of thought, we have recognized and sought to build upon criminologically-specific meanings of the term "security". These meanings, as Lucia Zedner (2009) has noted, differ considerably from the meanings accorded to this term in other disciplinary contexts - for example, within political science and international relations, where "security" has long been closely associated with national defence (Rothschild, 1995). Of particular concern within these disciplines has been processes of "securitization" that often ensue when these "security" meanings are layered on events in ways that justify the use of "emergency powers" to govern them (see Wæver, 1993; Buzan and Wæver, 1997; Floyd, 2008; Floyd, 2010). Wæver (1995:95; see also Floyd, 2008 and 2010; Balzacq, 2010; Floyd and Matthew, 2013) summarizes these processes, and the normative concerns they raise, nicely when he writes:

... with the help of language theory, we can regard 'security' as a speech act. In this usage, security is not of interest as a sign that refers to something more real; the utterance itself is the act. By saying it [security] is done (as in betting, giving a promise, naming the ship). By uttering 'security', a state-representative moves a particular development into a specific area, and thereby claims a special right to use whatever means are necessary to block it (Wæver, 1995:55).

In Floyd's words, when an issue is successfully "securitized", it is moved "out of the sphere of normal politics and into the realm of emergency politics" (Floyd, 2010:1).

While these meanings have recently found their way into criminology ( see Loader, 2002; Neocleous, 2000; Zedner, 2009), within criminology the term "security" has long been associated with safety at an individual and community level - hence the tight coupling of the 
terms "safety and security" noted above. These well-established criminological meanings have recently been picked up, within a development studies literature, via the use of the phrase "human security" (Brundtland (1987); see also Dalby (2013:27) who has recently explicitly linked "human security" to the challenges of the Anthropocene).

In our coupling of the term "security" with "environment", within a criminological context where security has long been understood as interpersonal peace, my collaborators and I have sought to move in a different direction to thinkers who have coupled these terms within the context of national security. For example, as Kaplan (1994) did, albeit implicitly, in his influential piece on "the coming anarchy" in which Nature is reimagined as yet another "hostile power" and where deteriorating environmental services are viewed as constituting "the national security issue of the early twenty-first century" (Kaplan, 1994:58).

For us, as our colleague Cameron Harrington (2015) at the Global Risk Governance Programme at the University of Cape Town has recently argued, conceiving of environmental security through the lens of "securitization" as a feature of "emergency politics" is inappropriate. What is appropriate is a return to the understandings of security that the phrase "safety and security" references - to meanings that put "people rather than states at the heart of the analysis" (Dalby 2009: 170). In taking this stance we have, in our use of the term (see for example Froestad and Shearing, 2013:154), sought to pick up on the meanings developed within ecological thinking. For example, in Rockstrom's notion (Rockstrom et al., 2009) of a "safe operating space for humanity" and Raworth's (2012) associated notion, of "a safe and just space for humanity”.

In joining "environment" and "security", we have sought to build upon, and expand, the established criminological understandings of security as "peace" and "peacekeeping" understandings that have, as I have already noted, a very long lineage within criminology. We have sought to broaden these well-established meanings beyond their exclusive focus on human-to-human engagements and to extend them so that they include thing-to-human and human-to-thing engagements (cf. Hillyard, 2004; Hillyard and Tombs, 2007 above). In doing so we have drawn inspiration from an emerging set of specific terms that "human security" is often used to reference terms such as "water security", "energy security", "food security", "climate security" and so on. Within this context we have conceived of "environmental security" as the umbrella term, which includes these and other environmentally-focused securities (and the associated insecurities). 


\section{Exploration in Environmental Security}

I turn now to exploring what a criminologically-situated notion of "environmental security" might look like. I will do so via examples of the research we have been engaged in under the sign of "environmental security". In this research we have adopted the approach outlined by Mariana Valverde (Valverde, 2014:383) in the published version of her 2013 lecture where she writes that:

While the theories and histories of security that we now have are certainly useful to criminology, it may be time to move to a different type of project, one that instead of focusing on security as a noun, a thing - a choice that inevitably leads into normative discussions about good security versus bad security - turns the gaze not on a single word or a concept but rather on the very wide variety of activities and practices that are being carried out under the name of 'security'.

In our use of terms like "security governance" and "environmental security" we have, for reasons I have canvased, deliberately eschewed the meanings of "security" associated with "national security", with its abiding geopolitical concerns with "containment and exclusion". The meanings we have sought to embrace echo Dalby (Dalby, 2002:60), in his use of the term "security" when he writes that

...security is not about protecting a stable status quo from an external threat. It is about developing an economic system that reduces dependence on a single resource, a dynamic system that can accommodate change. This does not fit easily into traditional understandings of defense or national security, which is, of course, the whole point of trying to rethink security.

In seeking to walk this analytic road, my colleagues and I have taken comfort from the fact that Nigel South (2012) has recommended that criminology, as it faces the challenges of the Anthropocene, should consider exploring the lens of "environmental (in)security" as it seeks to reimagine itself.

Through this programme of work, we have sought to develop a criminological response to the challenge of the Anthropocene that draws upon, and contributes to an understanding of, in Valverde's words, "the very wide variety of activities, practices that are being carried out under the name of "security", (Valverde, 2014:383). This extends and develops work that I 
have been engaged in, with others, for some time under the signs "security governance" and "nodal governance" (see for example, Shearing and Wood, 2003; Wood and Shearing, 2007; Froestad and Shearing, 2013; Shearing and Johnston, 2013).

In pursuing this research agenda we have sought to be both principled and pragmatic. At the level of principle, a foundational motivation has been to locate "fulcrum institutions", that is, institutions that occupy influential positions in nodal assemblages and networks, and which are threatened by the erosion of ecological systems upon which they depend, in one way or another.

In seeking out influential business within the private sector we have taken the stance that significant action intended to enhance "environmental security" has been, and is, taking place within contemporary forms of capitalism. This stance places us at odds with the advice of many thinkers, particularly Marxist scholars (Escobar, 2011; Foster, 2005; Fournier, 2008; Kallis, 2011), who question whether businesses operating within a capitalist economy can fundamentally shift their relationship to earth systems, given their established, and it is argued necessary, practices of externalizing the costs of resource extraction and waste.

The position we have adopted is aligned with the "varieties of capitalism" (Hall and Soskice, 2001; Hancké, 2009) and "regulatory capitalism" (Levi-Faur, 2006a; Levi-Faur 2006b; Braithwaite, 2008) approaches, which view capitalism as a "constitutively" regulated activity (Shearing, 1993) that takes different forms, and moves in different directions, within different regulatory environments. While distancing ourselves somewhat from the Marxist approach to environmental security we do, however, acknowledge, and value, Marx's neglected ecological critiques of the capitalist economy that Foster (2000), for example, has recognised.

In our research we have worked across the public, private and civil society sectors to explore the conditions under which fulcrum institutions change, and resist change, with respect to their engagements with earth systems. A particular focus of this work has been on understanding the often very significant regulatory reach of fulcrum institutions within the networks in which they are located.

This focus on conditions that shape engagements with earth systems has led us to develop a continuingly evolving conceptual model for understanding institutional change, which we have tentatively identified by the acronym AMP. This model arises, in large part, out of what nodal governance theorists have been discovering about the mentalities, technologies and 
resources of nodes in security assemblages and networks. The "A" in AMP refers to awareness understood as framing in Dorothy Smith's (2005) sense, with its resonances to Foucault's notion of "problematization", that a way of seeing is also a way of not seeing. The " $\mathrm{M}$ " refers to motivation, and in particular incentives and how they shape organizational decision-making. The "P" refers to perceived "Pathways" for action. We have been using this model, particularly in work being undertaken in partnership with WWF (World Wide Fund for Nature), to identify the conditions under which organizations will shift their engagements with earth systems.

Our research has been pragmatic (and opportunistic), as the choice of projects undertaken have been shaped by access and funding opportunities. To date this work has involved projects that have engaged municipalities (see for example Froestad et al., 2012; Pasquini and Shearing, 2014), the insurance industry (see for example Herbstein et al., 2013; Nel, Shearing, and Reyers, 2011), the marine industries and agriculture (Honig et al., forthcoming; Petersen et al., 2015). What has integrated these projects has been a set of crosscutting analytic questions, that AMP references, focused on understanding the institutional conditions that shape human engagements with earth systems.

This body of work, which is in its infancy, was initiated through an Australian-focused study, which sought to identify the conditions that shaped environmentally-focused collaborative governance initiatives (Holley, Gunningham, and Shearing, 2012). In this study we adopted a nodal governance framework to explore, and understand, attempts by Australian governments to incentivize institutional actors - across public, private and civil society sectors - to collaborate in ways that would shift their environmental engagement practices. A second leg of this work is presently being undertaken within South Africa where we are working, again with WWF, to explore conditions under which users of a single river system, the Umgeni River in Kwa Zulu-Natal, are willing to collaborate in managing this ecological system.

Our most recent research on "environmental security" - that we have only just begun -- is centred on the issue of "energy security". This project is exploring the impact of regulation on the nature of energy-generation regimes in the BRICS countries - Brazil, China, India and South Africa, but excluding Russia.

\section{Conclusion}

By way of conclusion let me return to another issue that Mariana Valverde (2013) raised in 
reflecting on the contours of a security-focused criminology. These reflections led her to wonder just how far criminological research can drift away "from the central notion of crime ... before leaving criminology altogether" (Valverde, 2013:1). She went on to note that "studying security" may well lead us beyond "criminology proper".

This question is most certainly relevant to the work I have outlined. Can this research be regarded as criminology? The question is especially pertinent given that the published work that I have cited has, as yet, not appeared in publications that are recognizably criminological.

How one answers this query depends, of course, on how one defines criminology and what indicators one regards as appropriate for assessing whether work is criminological. If ones definition of criminology is that it is "all about crime and criminal justice", as one of my colleagues said to me recently, then the research I have outlined is most certainly not criminology - while the work of the "green criminologists", for the most part, is.

My answer, not surprisingly, has been, and is, that the research I have outlined not only fits within criminology and that pursuing lines of enquiry that challenge criminology's established boundaries is crucial if it is to continue to advance understandings of the governance of security. That I have adopted this stance has much to do with my personal academic history - a history that was profoundly shaped by my long period at the University of Toronto where criminology was understood as an area of enquiry that was fundamentally interdisciplinary in nature and where "safety" (Hobbes" "peace") was located at the centre of the criminological stage. It is thus not surprising that Mariana Valverde, who was until recently the Director of the Centre of Criminology, Toronto, should have argued that criminology should continue to trace the shifting definitions of "safety and security".

At Toronto's Centre of Criminology (now the Centre of Criminology and Legal Studies) the term "criminology" has been used figuratively as a metonym in which "crime" was used to stand for a wider and more inclusive whole. Accordingly, outstanding criminological scholars at the Centre, such as Richard Ericson, never hesitated to undertake work that was both "proper" (for example his work on police) and "improper" (for example his insurance work) as he followed shifts in definitions of (in)security and associated developments in regulatory institutions. This focus has also found favour in Australia at the Australian National University at Regnet (the Regulatory Institutions Network), for example in the work of John Braithwaite and Peter Grabosky. 
In taking this stance in both my current and earlier work I have not only argued for an inclusion of the "old" with the "new", but have sought to find ways of enabling established understanding to engage with developing ones and vice versa. This has been my hope in juxtaposing a "green crime-ology" with a "green security-ology" under the umbrella of a developing, and inclusive, criminology within the Anthropocene.

With your indulgence I would like to close the way I began -- on a personal note.

Today, it is not I asking questions of my father. Rather, it is my "grandchildren" who are asking questions of me. What keeps me up at night, every so often, is not the questions that they are asking me now, but rather a question I imagine they might ask me very soon as they emerge as young adults. The question I imagine they might pose is: "Granddad, what did you do once you became aware of this Human Age that we will be living our lives in?"

A terrifying question. 


\section{References}

Balzacq T (2010) Securitization Theory: How Security Problems Emerge and Dissolve. London: Routledge.

Bayley D and Shearing C (2001) The New Structure of Policing: Description, Conceptualization, and Research Agenda. Washington, DC: U.S. Department of Justice.

Beck U (1992) Risk Society: Towards a New Modernity. Thousand Oaks, CA: Sage Publications.

Braithwaite J (2000) The New Regulatory State and the Transformation of Criminology. British Journal of Criminology 40:222-238.

Braithwaite J (2008) Regulatory Capitalism: How It Works, Ideas for Making It Work Better. Cheltenham: Edward Elgar Publishing.

Brisman A and South N (2013) A Green-Cultural Criminology: An Exploratory Outline. Crime Media, Culture 9(2): 115-135.

Brundtland GH (1987) Our Common Future: The World Commission on Environment and Development. Oxford: Oxford University Press.

Buzan B and Wæver O (1997) Slippery? Contradictory? Sociological untenable? The Copenhagen School replies. Review of International Studies 23(2):241-250.

Chakrabarty D (2009) The Climate of History: Four Theses. Critical Inquiry, 35(2):197-222.

Cohen L (1992) The Future. New York: Columbia Records.

Corlett RT (2015) The Anthropocene concept in Ecology and Conservation. Trends in Ecology \& Evolution 30(1): 36-41.

Council for Canadian Academies (2014) Policing Canada in the 21st Century: New Policing for New Challenges. Ottawa: Council for Canadian Academies.

Crutzen PJ and Stoermer EF (2000) The 'Anthropocene'. Global Change Newsletter 41: 1718. 
Dalby S (2002) Environmental Security. Minneapolis: University of Minnesota Press.

Dalby S (2007) Anthropocene Geopolitics: Globalisation, Empire, Environment and Critique. Geography Compass 1/1: 103-118.

Dalby S (2009) Security and Environmental Change. Cambridge: Polity Press.

Dalby S (2013) Human Security in the Anthropocene: The Implications of Earth System Analysis. In: Synga L, O'Brien K and Wolf J (eds) A Changing Environment for Human Security. Oxon and New York: Routledge, pp. 27-33.

Dalby S (2014) Rethinking Geopolitics: Climate Security in the Anthropocene. Global Policing 5(1): 1-9.

Escobar A (2011) Encountering development: The making and unmaking of the Third World. Princeton: Princeton University Press.

Finney F (2014) The "Anthropocene" as a ratified Unit in the ICS International Chronostratigraphic Chart: Fundamental Issues that must be addressed by the Task Group. Geological Society London Special Publications 395: 23-28.

Floyd R (2008) The Environmental Security Debate and its Significance for Climate Change. The International Spectator: Italian Journal of International Affairs 43(3): 51-65.

Floyd R (2010) Security and the Environment: Securitisation Theory and US Environmental Security Policy. Cambridge: Cambridge University Press.

Floyd R and Matthew R (2013) Environmental Security Studies: An Introduction. In: Floyd R (eds) Environmental Security: Approaches and Issues. New York: Routledge, pp. 1-20.

Foster J (2005) The Vulnerable Planet. In: King L and McCarthy D (eds) Environmental Sociology: From Analysis to Action. London: Rowman and Littlefield Publishers, pp. 25-37.

Foster JB (2000) Marx's Ecology: Materialism and Nature. New York: Monthly Review Press.

Foucault M (1988) Practising criticism. In: Kritzman LD (eds) Politics, Philosophy, Culture: Interviews and Other Writings 1977-1984. New York: Routledge, pp. 152-156. 
Fournier V (2008) Escaping from the Economy: The Politics of Degrowth. International Journal of Sociology and Social Policy 28(11/12): 528-545.

Froestad J, Shearing C, Herbstein T and Grimwood S (2012) City of Cape Town Solar Water Heater Bylaw: Barriers to Implementation. In: Cartright A Parnell S Oelofse G and Ward S (eds) Climate Change at the City Scale: Impacts, Mitigation and Adaptation in Cape Town. Oxon: Earthscan, pp. 244-262.

Froestad J and Shearing C (2013) Security Governance, Policing, and Local Capacity. Boca Raton: CRC Press.

Garfinkel H (1967) Studies in Ethnomethodology. Englewood Cliffs: Prentice Hall.

Gibbs C, Gore ML, McGarrell EF and Rivers L (2010) Introducing Conservation Criminology: Towards Interdisciplinary Scholarship on Environmental Crimes and Risks. British Journal of Criminology 50:124-144.

Hackmann H, Moser SC and St. Clair AL (2014) The Social at the Heart of Global Environmental Change. Nature Climate Change 4(8): 653-655.

Hall P and Soskice D (2001) Varieties of capitalism: The institutional foundations of comparative advantage. Oxford: Oxford University Press.

Halsey M (2004) Against “Green” Criminology. British Journal of Criminology 44: 833-853.

Halsey M (2013) Conservation Criminology and the "General Accident" of Climate Change. In: South N and Brisman A (eds) Routledge International Handbook of Green Criminology. London and New York: Routledge, pp. 107-119.

Halsey M and White R (1998) Crime, Ecophilosophy and Environmental Harm. Theoretical Criminology 2(3): 345-371.

Hamilton C (2013a) Earthmasters: The dawn of the age of climate engineering. New Haven, CT: Yale University Press. 
Hamilton C (2013b) Climate change signals the End of the Social Sciences. Conversation, 26 January 2013. Available at: http://theconversation.com/climate-change-signals-the-end-ofthe-social-sciences-11722 (accessed 17 February 2015).

Hancké B (2009) Debating Varieties of Capitalism. Oxford: Oxford University Press.

Harrington C (2015) Environmental security and the Anthropocene. In: 2015 International Studies Association Annual Conference. New Orleans, LA, USA, 21 February 2015.

Hegel GW (1896) Hegel's Philosophy of Right. Oxford: Oxford University Press.

Heidegger M (1977) The Question Concerning Technology and Other Essays. New York and London: Garland Publishing, Inc.

Herbstein T, Froestad J, Nel D and Shearing C (2013) Insurance, Climate-Risk and the Barriers to Change. In: Börzel TA and Hamann R (eds) Business and Climate Change Governance: South Africa in Comparative Perspective. London: Palgrave Macmillan, pp. $156-172$.

Hillyard P (2004) Beyond Criminology: Taking Harm Seriously. London: Pluto Press.

Hillyard P and Tombs S (2007) From "Crime" to Social Harm? Crime, Law and Social Change 48(1-2): 9-25.

Holley C, Gunningham N and Shearing C (2012) The New Environmental Governance. Abingdon: Earthscan.

Honig M, Petersen S, Herbstein T, Roux S, Nel D and Shearing C (Forthcoming) A conceptual framework to enable the changes required for a one-planet future. Environmental Values.

Johnston L and Shearing C (2003) Governing Security Explorations in Policing and Justice. London: Routledge.

Kallis G (2011) In Defence of Degrowth. Ecological Economics 70(5): 873-880.

Kaplan R (1994) The coming Anarchy. Atlantic Monthly 273(2): 44-76. 
Larner W (2011) C-change? Geographies of crisis. Dialogues in Human Geography 1(3): 319-335.

Latour B (1993) We Have Never Been Modern. Cambridge, MA: Harvard University Press.

Latour B (2005) Reassembling the Social: An Introduction to Actor-Network-Theory. Oxford: Oxford University Press.

Levi-Faur D (2006a) Regulatory Capitalism: The Dynamics of Change beyond Telecoms and Electricity. Governance 19(3): 497-525.

Levi-Faur D (2006b) Varieties of Regulatory Capitalism: Getting the Most Out of the Comparative Method. Governance: An International Journal of Policy, Administration, and Institutions 19(3): 367-382.

Loader I (2002) Policing, Securitization and Democratization in Europe. Criminology and Criminal Justice 2(2):125-153.

Lynch M (1990) The Greening of Criminology: A Perspective on the 1990s. The Criminologist 2(3): 1-4.

Lynch MJ and Stretesky PB (2003) The Meaning of Green: Contrasting Criminological Perspectives. Theoretical Criminology 7(2): 217-238.

March JG (1991) Exploration and Exploitation in Organizational Learning. Organizational Science 2(1): 71-87.

Natali L (2013) The Contemporary Horizon of Green Criminology. In: South N and Brisman A (eds) Routledge International Handbook of Green Criminology. London: Routledge, pp. 73-84.

Nel DC, Shearing C and Reyers B (2011) Insurers Could Help Address Climate Risks. Nature 476(7358):33.

Neocleous M (2000) The Fabrication of Social Order: A Critical Theory of Police Power. London: Pluto Press. 
Palsson G, Szersynski B, Sörlin S, Marks J, Avril B, Crumley C, Hackmann H, Holm, P, Ingram J, Kirman A, Buendia MP and Weehuizen R (2013) Reconceptualizing the 'Anthropos' in the Anthropocene: Integrating the Social Sciences and Humanities in Global Environmental Change Research. Environmental Science and Policy 28: 3-13.

Pasquini L and Shearing C (2014) Municipalities, Politics, and Climate Change: An Example of the Process of Institutionalizing an Environmental Agenda within Local Government. Journal of Environment \& Developmen, 23(2): 271-296.

Petersen S, Shearing C and Nel D (2015). Sustainability Transitions: An Investigation of the Conditions under Which Corporations Are Likely To Reshape Their Practices to Reverse Environmental Degradation. Environmental Management and Sustainable Development 4(1): 85-105.

Raworth K (2012) A Safe and Just Space For Humanity: Can we live within the Doughnut? Nature 461: 1-26.

Rockstrom J, Steffen W, Noone K, Persson Å, Stuart Chapin III F, Lambin EF, Lenton TM, Scheffer M, Folke C, Schellnhuber HJ, Nykvist B, de Wit CA, Hughes T, van der Leeuw S, Rodhe H, Sörlin S, Snyder PK, Constanza R, Svedin U, Falkenmark M, Karlberg L, Corell RW, Fabry VJ, Hansen J, Walker B, Liverman D, Richardson K, Crutzen P, and Foley JA. (2009) A Safe Operating Space For Humanity. Nature 461: 472-475.

Rose N (1996) The death of the Social? Re-figuring the Territory of Government. Journal of Human Resource Management 24(3): 327-356.

Rothschild E (1995) What is Security? Daedalus 124(3): 53-98.

Shearing C (1993) A Constitutive Conception of Regulation. In: Grabosky P and Braithwaite J (eds) Business Regulation and Australia's Future. Canberra: Australian Institute of Criminology, pp. 67-79.

Shearing C and Johnston L (2013) Governing Security: Explorations of Policing and Justice. London: Routledge.

Shearing C and Wood J (2003) Nodal Governance, Democracy, and the New "Denizens". Journal of Law and Society 30(3): 400-419. 
Simon J (2007) Governing through Crime: How the War on Crime transformed American Democracy and created a Culture of Fear. Oxford: Oxford University Press.

Smith D (1987) The Everyday World As Problematic: A Feminist Sociology. Boston: Northeastern University Press.

Smith D (2005) Institutional Ethnography: A Sociology for People. Toronto: Altamira Press.

South N (2012) Climate Change, Environmental (In)Security, Conflict and Crime. In: Farrall S Ahmed T and French D (eds) Criminological and Legal Consequences of Climate Change. Oxford: Hart Publishing, pp. 97-112.

South N and Brisman A (2013) Routledge International Handbook of Green Criminology. London: Routledge.

Syvitski J (2012) Anthropocene: An Epoch of our Making. Global Change 78: 12-15.

Tallacchini M (1998) Introduzione. Una Scienza per la Natura, una Filosofia per la Terra. In: Tallacchini M (eds) Etiche della Terra, Antologia di Filosofia dell' Ambiente. Milan: Vita e Pensiero, pp 1-57.

Tudge C (1998) Neanderthals, Bandits and Farmers: How Agriculture really began. New Haven, CT: Yale University Press.

Valverde M (2013) Time and Space in the Governance of Crime and Security. In: Criminology and Criminal Justice Journal Lecture for 2013, Leeds, UK, 16 October 2013.

Valverde M (2014) Studying the Governance of Crime and Security: Space, Time and Jurisdiction. Criminology and Criminal Justice 14(4): 379-391.

Wæver O (1993) Securitization and Desecuritization. Copenhagen: Centre for Peace and Conflict Studies.

Wæver O (1995) Securitization and Desecuritization. In: Lipschutz R (eds) On Security. New York: Colombia University Press, pp. 46-86.

White L (1967) The Historical Roots of Our Ecological Crisis. Science 155:1203-1207. 
White R (2003) Environmental Issues and the Criminological Imagination. Theoretical Criminology 7(4): 483-506.

White R (2009) Researching Transnational Environmental Harm: Toward an Eco- Global Criminology. International Journal of Comparative and Applied Criminal Justice 33(2): 229248.

White R (2014) Environmental Insecurity and Fortress Mentality. International Affairs 90(4): $835-851$.

White R and South N (2013) The Future of Green Criminology: Horizon Scanning and Climate Change. In: American Society of Criminology Annual Meeting, Atlanta Marriott Marquis, Atlanta, GA, 20-23 November 2013.

Wood J and Shearing C (2007) Imagining Security. London: Willan.

Zedner L (2009) Security: Key Ideas in Criminology Series. London and New York: Routledge. 